\title{
PEMERIKSAAN TELUR CACING PADA KOTORAN KUKU DAN PERSONAL HYGIENE SISWA KELAS I SD NEGERI 1 BATUANTEN KECAMATAN CILONGOK KABUPATEN BANYUMAS TAHUN 2015
}

\author{
Iqbal Mei Rizki Lutfiansyah' ${ }^{1)}$, Lagiono ${ }^{2)}$ \\ Jurusan Kesehatan Lingkungan, Politeknik Kesehatan Kemenkes Semarang, \\ Jl. Raya Baturaden KM 12 Purwokerto, Indonesia
}

\begin{abstract}
Abstrak
Kecacingan suatu bentuk infeksi oleh cacing yang ditularkan melalui perantara tanah ke manusia. Infeksi cacing dewasa menyebabkan gangguan pencernaan, pendarahan, anemia,kurang gizi dan iritasi usus. Personal hygiene adalah suatu usaha pemeliharaan kesehatan diri seseorang yang bertujuan mencegah terjangkitnya penyakit serta untuk memperbaiki status kesehatannya. Tujuan penelitian ini untuk mengetahui ada tidaknya telur cacing pada kotoran kuku dan mendeskripsikan personal hygiene siswa kelas I SD Negeri 1 Batuanten. Jenis penelitian ini adalah deskriptif dimaksudkan untuk mendiskripsikan secara sistematis dan akurat suatu situasi atau area populasi tertentu yang bersifat aktual. Populasi penelitian ini adalah siswa kelas I SD Negeri 1 Batuanten. Pengumpulan data dilakukan dengan pemeriksaan laboratorium dan wawancara dengan responden. Hasil pemeriksaan kotoran kuku adalah semua siswa memiliki hasil yang negatif. Data dianalisis dengan analisis deskriptif dengan mengunakan prosentase data dalam tabel dan dibandingkan dengan teori. Hasil penelitian menunjukkan hasil negatif pada kuku siswa, tapi dalam pemeriksaan tersebut ditemukan feses pada kotoran kuku tersebut. Hal ini menandakan bahwa pada kotoran kuku siswa tersebut masih kotor. Sedangkan pada indikator personal hygiene yaitu 6 siswa masuk kategori baik, 14 siswa masuk kategori cukup baik dan 1 siswa masuk kategori kurang baik.
\end{abstract}

Kata Kunci : Kecacingan, Siswa SD, Personal Hygiene, Kesehatan Lingkungan

\begin{abstract}
[Worm Egg Assessment on Nail dand Personal Hygiene of First Grader at AD Negeri 1 Batuanten, Cilongok District Banyumas Regency Year of 2015] Helminthiases a form of infection by worms transmitted to humans through soil agent. Adult worm infections cause indigestion, bleeding, anemia, malnutrition and intestinal irritation. Personal hygiene is an individual health maintenance aimed to preventing disease and to improve their health status. The Research objectives were determining whether there is a worm eggs in nails and describe personal hygiene of first grade students of SD Negeri 1 Batuanten. This research design used was descriptive design which intended to systematically and accurately describe a recent situation or specific area populations. The research sample was first grade students of SD Negeri 1 Batuanten. The research data was collected through laboratory tests and interviews with respondents. The nail dirt laboratory examination shows that; all of students had negative results. The obtained data were analyzed with descriptive analysis using data percentage showed in the table form and compared with theory. The examination results showed a negative result, but feces in was found on the nail dirt. This indicates that the student had dirty fingernails. While the personal hygiene indicators show that 6 students had good personal hygiene, 14 students in the "fair" category and 1 student had bad personal hygiene.
\end{abstract}

Keywords : Helminthiases, Elemtary Student, Personal Hygiene, Environmental Health

\section{PENDAhUluan}

Personal hygiene adalah suatu usaha pemeliharaan kesehatan diri seseorang yang bertujuan mencegah terjangkitnya penyakit serta untuk memperbaiki status kesehatannya. Salah satunya indikator dari personal hygiene adalah perawatan kaki, tangan dan kuku (Perry dan Potter, 2005).

Kebersihan kaki, tangan dan kuku menjadi hal yang penting untuk diperhatikan kebersihannya terutama ketika sedang sakit, perawatannya menjadi semakin penting untuk diperhatikan. Kuku yang tidak terawat juga dapat mengakibatkan masalah kesehatan. Beberapa masalah akibat tidak terawatnya kuku misalnya kuku yang panjang dapat mengakibatkan kuku menjadi mudah robek dan dapat melukai kulit sekitar kuku karena pemotangannya yang salah (Isro'in dan Andarmoyo, 2012).

Kuku yang panjang dan tidak terawat akan menjadi tempat melekatnya berbagai kotoran yang mengandung berbagai bahan dan mikroorganisme diantaranya bakteri dan telur cacing. Penularan

1) Email : meiiqbal@ymail.com

2) Email : lagionoabdulwahid@yahoo.co.id 
cacingan diantaranya melalui tangan yang kotor. Kuku jari tangan yang kotor yang kemungkinan terselip telur cacing akan tertelan ketika makan, hal ini diperparah lagi apabila tidak terbiasa mencuci tangan memakai sabun sebelum makan (Luize, 2004 dan Onggowaluyo, 2002).

Anak sekolah dasar (SD) merupakan masa tumbuh kembang yang baik. Masa-masa ini anak perlu mendapatkan pengawasan terhadap kesehatannya karena usia sekolah adalah masa dimana anak-anak mempunyai banyak aktivitas, dan aktivitas tersebut seringkali berhubungan langsung dengan lingkungan yang kotor dan menyebabkan anak-anak juga seringkali mudah terserang penyakit. Perawatan kuku pada anak-anak juga seringkali terabaikan oleh orang tua. Kurangnya pengetahuan dan kesadaran orang tua dalam memperhatikan personal hygiene anak menyebabkan anak juga tidak memperhatikan kebersihan dirinya sendiri. Meskipun terlihat sepele, tetapi perawatan kuku juga merupakan hal penting yang harus diperhatikan (Wong, 2009).

Penelitian yang dilakukan oleh Kusuma (2011) didapatkan data tentang tingkat pengetahuan anak usia Sekolah Dasar tentang kecacingan dalam kategori baik 13,1 \%, sedang 48,2 \%, dan rendah $38,7 \%$. Sedangkan sikap baik $48,2 \%$ dan cukup baik $51,8 \%$. Hasil penelitian juga didapatkan data bahwa perilaku merawat kuku seminggu sekali pada siswa SD sebanyak $64,2 \%$.

Penelitian yang dilakukan pada tahun 2012 mendapatkan hasil bahwa kebersihan kuku mempunyai hubungan yang erat dengan kejadian kecacingan pada siswa SD. Siswa SD yang mempunyai kuku kotor dan panjang mempunyai resiko lebih besar untuk terkena kecacingan. Sebanyak $60 \%$ siswa positif terkena kecacingan dan $40 \%$ lainnya negatif (Fitri,dkk, 2012). Penelitian Texanto dan Hendratno (2008) menunjukkan bahwa $10,7 \%$ dari 56 siswa terinfeksi soil transmitted helminthes dimana dari hasil kuesioner didapatkan $7,1 \%$ anak dengan hygiene kurang. Suvei yang pernah dilakukan oleh Depkes RI tahun 2003 didapatkan data $85,8 \%$ anak usia sekolah di Kabupaten Pesisir Selatan mengalami kecacingan (Depkes RI, 2003)

SD Negeri 1 Batuanten merupakan salah satu sekolah dasar yang berada di Kecamatan Cilongok Kabupaten Banyumas. Lokasi SD Negeri 1 Batuanten ada didaerah pedesaan, dikelilingi oleh persawahan dan lapangan yang digunakan untuk bermain seharihari masih lapangan tanah.

Hasil studi pendahuluan yang telah dilakukan pada siswa kelas I SD Negeri 1 Batuanten didapatkan data jumlah siswa adalah 21 anak. Hasil Observasi kebersihan kuku yang dilakukan pada siswa kelas I didapatkan data 14 siswa mempunyai kuku yang panjang dan kotor dan kebanyakan dari mereka tidak mengetahui cara merawat kuku yang benar. Hasil wawancara dengan salah satu guru kelas didapatkan informasi bahwa SD Negeri 1 Batuanten belum pernah mendapatkan penyuluhan kesehatan, terutama yang berkaitan dengan perawatan kuku.

\section{BAHAN DAN METODE}

Jenis penelitian ini adalah penelitian survey yang bersifat deskriptif. Penelitian deskriptif dimaksudkan untuk mendiskripsikan secara sistematis dan akurat suatu situasi atau area populasi tertentu yang bersifat aktual (Sudarwan Danim, 2003 : 52).

Sampel yang digunakan dalam penelitian ini adalah populasi siswa kelas I SD Negeri 1 Batuanten.

\section{III.HASIL DAN PEMBAHASAN}

Hygiene adalah usaha kesehatan masyarakat yang mempelajari kodisi lingkungan terhadap kesehatan manusia, upaya mencegah timbulnya penyakit karena pengaruh lingkungan serta membuat kondisi lingkungan sedemikian sehingga menjamin pemeliharaan kesehatan.

Kuku yang panjang dan tidak terawat akan menjadi tempat melekatnya berbagai kotoran yang mengandung berbagai bahan dan mikroorganisme diantaranya bakteri dan telur cacing. Penularan cacingan diantaranya melalui tangan yang kotor. Kuku jari tangan yang kotor yang kemungkinan terselip telur cacing akan tertelan ketika makan, hal ini diperparah lagi apabila tidak terbiasa mencuci tangan memakai sabun sebelum makan (Luize, 2004)

Hasil pemeriksaan yang telah dilakukan pada kotoran kuku pada 21 siswa kelas I SD Negeri 1 Batuanten di Laboratorium Kesehatan Masyarakat Purwokerto bagian Biologi adalah semua siswa memiliki hasil yang negatif, itu artinya tidak ditemukan adanya telur cacing pada kotoran kuku siswa kelas I SD Negeri 1 Batuanten. Tetapi dalam pemeriksaan tersebut banyak pada kotoran kuku siswa tersebut ditemukan feses pada kotoran kukunya. Hasil tersebut menunjukkan bahwa kuku siswa tersebut telah terkontaminasi dengan feses yang menjadi media telur cacing.

Hasil wawancara responden dan observasi pada aspek personal hygiene di kelas I SD Negeri 1 Batuanten Kecamatan Cilongok Kabupaten Banyumas pada 21 siswa didapatkan hasil yaitu, 6 siswa dikategorikan baik dengan prsentase 28,57\%, 14 siswa dikategorikan cukup baik dengan presentase 66,67\%, 1 siswa dikategorikan kurang baik dengan presentase $4,76 \%$, dan siswa yang dikategori tidak baik memiliki presentase $0 \%$.

Dari hasil wawancara responden aspek personal hygiene siswa kelas I SD Negeri 1 Batuanten Kecamatan Cilongok Kabupaten Banyumas sebagian besar kategori cukup baik dengan presentase 66,67\% dan dari hasil observasi didapatkan hasil masih banyak siswa yang memiliki kuku yang panjang dan kotor. Selain itu juga masih banyak siswa yang belum membiasakan mencuci tangan menggunakan sabun setelah buang air besar. 


\section{IV.KESIMPULAN}

1. Dalam pemeriksaan telur cacing pada kotoran kuku siswa kelas I SD Negeri 1 Batuanten tidak ditemukan adanya telur cacing.

2. Tidak ada jenis telur cacing pada kotoran kuku siswa karena tidak ditemukan adanya telur cacing pada kotoran kuku.

3. Personal Hygiene siswa kelas I SD Negeri 1 Batuanten sudah cukup baik.

\section{DAFTAR PUSTAKA}

Azrul Ajimul Hidayat, 2007, Pengertian Devinisi Operasional Variabel

Azwar. A, 1993.Pengantar Ilmu Kesehatan Lingkungan. Jakarta : Mutiara.

Danim, Sudarwan. 2003. Riset Keperawatan : Sejarah\&Metodologi. Jakarta : EGC.

Depkes RI, 1992.Marilah Memberantas dan Mencegah Kecacingan. Jakarta : P2M-PLP.

Depkes RI, 1998.Pedoman Program Pemberantasan Penyakit Kecacingan, Jakarta : P2M-PLP.

Depkes RI, 2003. Pedoman Penemuan dan Pengobatan Penderita Tuberkulosis Paru. Ditjen PMM \& PLP Depkes RI : Jakarta.

Depkes RI, 2004. Hygiene Sanitasi Makanan dan Minuman. Jakarta : P2M-PL.

Depkes RI, 2004. Program Nasional Pemberantasan Cacingan di Era Desentralisasi, Jakarta : Subdit Diare dan Penyakit Pencernaan.

Depkes RI, 2006. Pedoman Teknis Sarana dan Prasarana Bangunan Instalasi Bedah, Jakarta : Direktorat Jendral Bina Pelayanan Medik.

Depkes RI, 2007. Rumah Tangga Sehat Dengan Perilaku Hidup Bersih dan Sehat, Jakarta : Pusat Promosi Kesehatan.

Departemen Kesehatan RI. 2009. Rencana Pembangunan Jangka Panjang Bidang Kesehatan 2005-2025. Jakarta: Depkes RI.

Entjang, I., 2000. Ilmu Kesehatan Masyarakat. Bandung : PT. Citra Aditya Bakti.

Fitri, dkk, 2012. Penelitian Tindakan Kelas Untuk Tenaga Pendidik Profesional. (Yogyakarta: PT Pustaka Insan Madani)

Gandahusada, S., 2000. Parasitologi Kedokteran Edisi II. Jakarta : FKUI.
Gay, L.R dan Diehl, P.L., 1992. Research Methods for Business and Management, New York : MacMillan Publishing Company.

Isro'in \& Andarmoyo, (2012), Personal Hygiene : Konsep, Proses dan Aplikasi dalam praktek keprawatan, edisi pertama, Yogyakarta : Graha Ilmu

Luize, A., 2004. Mengintip Kesehatan Lewat Buku. Jakarta

Mohammad, C. G.; Oothuman, P. and Cline, B. L., 1996. Intestinal Worm Discriminate the Levels of School Performance Rural Malaysian Primary School Children. Tokyo, Japan : APCO Parasitologist Meeting XVIII.

Onggowaluyo, J. S., 2002. Parasitologi Medik I, Jakarta : EGC.

Oswari, E., 1991. Penyakit dan Penanggulangan Petunjuk Praktis bagi Kaum Awam dan Paramedis. Jakarta : PT. Pustaka Pembangunan Swadaya Nusantara.

Perry \& potter, 2005, Buku Ajar Fundamental Kepratan: Konsep, Proses \& Praktek, Edisi 4. Vol I. Jakarta : EGC

Peter J. Hotes, 2003, Soil Transmitted Helminth Infection: The Nature Causes and Burden of the Condition, WHO : Department of Microbiology and Tropical Medicine the George Washington University.

Ramali, A., 1990. Kamus Kedokteran. Jakarta : Jambatan.

Sajimin, T., 2000. Gambaran Epidemiologi Kejadian Kecacingan pada Siswa SD di Kecamatan Ampera Kota Poso Sulawesi Tengah. Jurnal Epidemiologi Indonesia, volume 4, halaman $1-2$.

Suharsimi, Arikunto, 1992, Prosedur Penelitian suatu Pendekatan Praktek, Jakarta : rineka cipta.

Surat Keputusan Menteri Kesehatan No : 424/MENKES/SKNI/2006 tentang Pendoman Pengendalian Cacing.

Texanto dan Hendratno, 2008. Hubungan Antara Status Hygiene Individu Dengan Aangka Kejadian Soil Transmitted Helminth di SDN 03 Pringapus. Jurnal Universitas Diponegoro. Vol 2 no 5, Maret 2008 
Wong, 2009, Buku Ajar Keprawatan Pediatrik, Volume 2. Jakarta : EGC
Asmirah, 2006, Kejadian Infeksi Soil Transmitted Helminths Berdasarkan Perilaku Hidup 